\title{
Mechanized Cultivation Increases Labour Efficiency
}

\author{
A K MS Islam ${ }^{*}$
}

\begin{abstract}
Farm mechanization facilitates to increase agricultural productivity and improves farm management by replacing human labour. Therefore, mechanical intervention is a vital adaptation strategy for a sustainable rice production system. Thus, this study aims to (i) estimate the amount of mechanical intervention required in rice cultivation, particularly in transplanting and harvesting operation; and (ii) delineate the impact of farm mechanization on rice productivity and employment generation. The primary data were collected through a household survey and key informant interviews. These data were used for projecting rice area, labour requirement, and off-farm employment opportunities in rice cultivation. Besides, secondary data were collected from published literature. The break-even labour requirement per hectare rice cultivation was 2.88 work-days. Labour productivity might be doubled by 2030 subject to bringing $42 \%$ and $36 \%$ of the total rice area under mechanical transplanting and harvesting, respectively. The projected demands of the transplanter and combine harvester to achieve the goal are 49,172 and 28,382, respectively. The mechanized rice transplanting, weeding, and harvesting reduced labour requirement by 29,26 , and $34 \%$, respectively, compared to the manual operations. Besides, mechanization meets up the demand for labour at a seasonal peak and increases rice productivity. Furthermore, it creates some off-farm (e.g., operating) and non-farm (e.g., manufacturing, repairing, and trading) employment opportunities for operating, maintenance, fabricating, and marketing of the machinery. Syncronize farming is required for enhancing the field efficiency of the farm machine at present size and shape of plots. Besides, the synchronized farming is beneficial for providing service to the farmers at their affordable rental charge. Government assistance should continue and strengthen for the procurement of transplanters and combine harvesters. A holistic approach combining the public and private intervention is essential for achieving the mechanized farming goal for sustainable rice farming in Bangladesh.
\end{abstract}

Key words: Mechanization, transplanting, harvesting, rice labour, labour efficiency, break-even labour.

\section{INTRODUCTION}

Mechanization is the key to modernize agriculture. The government and nongovernment organizations in Bangladesh have been jointly working for modernizing agriculture through mechanization since early 1980. It is in part because of mechanized cultivation increases the yield and total system productivity through facilitating the early establishment of the following crops by reducing turn around time as well as decreases production cost (Islam, 2020). Mechanized cultivation is an option for sustainable farming using the decreasing labour force. Farm mechanization synonymous with rice farming mechanization in the country as rice covers about $80 \%$ of the total crop area, and ricebased cropping pattern is the most extensively practiced cropping system in Bangladesh (Kabir et al., 2015).

\section{Mechanization status}

Mechanical intervention in crop production was slowly progressing in the country since the early 1980s. However, the rate of adoption of farm machinery has increased substantially since mid-1990 because of import tax liberalization for two-wheel tractor and small diesel engine, and banning the standardization committee on farm machinery. The government has increased facilities for twowheel tractor instead of the four-wheel tractor because of its suitability with our environment (e.g., small plots) and socio-economic conditions (e.g., the low purchasing power of farmers). Farm mechanization in the country got momentum after 2009, when the government largely increased subsidies for agricultural mechanization. The combined efforts of different stakeholders, including the ministry, research institutes, extension agents,

\footnotetext{
${ }^{1}$ Farm Machinery and Postharvest Technology Division, Bangladesh Rice Research Institute, Gazipur-1701, Bangladesh. *Corresponding author's E-mail: akmsaifulislam68@gmail.com (A K M S Islam)
} 
development partners, manufacturers, traders, dealers, and farmers also played an important role in the momentum.

Currently, tillage, irrigation, spraying pesticides, and even the threshing are fully mechanized because of the above-mentioned government and other stakeholders' intervention. However, other labour-intensive major intercultural operations of rice farming like transplanting, fertilizer application, weeding, harvesting, and winnowing are still carried out by humanlabour. The scale of mechanized transplanting and harvesting in the country is extremely low because of the investment in rice transplanter and combine harvester ismuch beyond the purchasing ability of most farm households. Similarly, despite notable post-harvest loss, farmers of the country rely on the sun-drying of rice even in the early wet season and wet season due to scarce access to the mechanical drying facilities (Islam, 2018a). The farm mechanization status of the country is currently atthe development stage and far behind the fully mechanized countries such as Korea and Japan (Islam, 2016). Therefore, researchers and development partners are jointly working for developing an economically sustainable business model for expediting farm mechanization in Bangladesh through disseminating transplanter and combine harvester at farmers' fields by local service providers.

\section{Challenges for farm mechanization}

The key challenges of large scale farm mechanization in the country are included (i) the lack of suitable farm machines for the condition of Bangladeshi lands and small size plots, (ii) the low purchasing power of smallholder farmers, (iii) the absence of farm road, quality machines, service center, quality spare parts, replaceable tools, accessories, and skilled operators. Besides, lack of suitable infrastructural facilities for the research, development, manufacturing, and quality control also impeded the farm mechanization process in the country. Moreover, inadequate extension services are also a barrier for the dissemination of farm machinery as farmers are not always aware of the benefit of mechanized cultivation. Finally, lack of availability of rules for producing quality farm equipment, proper design and drawing, standard material, fabrication guidelines, skilled manpower, technical assistance, and credit facility as well as the higher tariff for raw material than machines are the barriers for producing farm machinery in the country.

\section{Farm mechanization policies in Bangladesh}

Formulating suitable policies considering the socio-economic and land conditions and a holistic approach are critically important for the sustainability of farm mechanization in a country. Following policies have been undertaken in Bangladesh for expediating farm mechanization.

(i) Department of Agriculture Extension (DAE) has taken a short-term program to provide $70 \%$ assistance for haor areas and $50 \%$ assistance for the other areas on the procurement of transplanter, reaper, and harvester in 2020. The Government of Bangladesh allocated Tk 200 crore budget to DAE to execute the program (MoA, 2020).

(ii) The government provided funds to Bangladesh Rice Research Institute (BRRI) to procures combine harvesters in 2009. BRRI organized some large-scale demonstrations on combine harvester at the farmer's field to motivate farmers for mechanized harvesting and threshing. Similarly, the government provided funds to DAE to influence farmers for purchasing combine harvester at subsidized prices. Initially, traders imported recondition harvester in one-tenth price, invested some money for repairing purposes, and sold to the farmers under the government subsidy programme (Islam, 2018a). The DAE also set some large 
scale demonstrations and provided training for operating and maintenance of combine harvester. About 1,748 combine harvesters of different makes and models are in operations at the farmer field in Bangladesh (Field survey, 2020). Farmers operated the machine to harvest the rice crops and side by side rented out the machine.

(iii) The government of Bangladesh provided funds to BRRI to procure transplanter for demonstration and training purposes in 2009. BRRI organized a demonstration on rice transplanters at farmer fields. Besides, provided training to the farmers on raising seedlings at trays. DAE also distributed the transplanters to the farmers at the government determined subsidized price. DAE also arranged largescale demonstrations and residential training programmes on the operation and maintenance of transplanters. Presently, 625 transplanters are in operations in the farmers' field (Field survey, 2020).

(iv) Before 1998, farmers usually threshed the paddy and wheat manually. As the labour price going up as well as labour shortage, it became an issue to thresh crops manually. Farmers had been compelled to thresh their crops in power thresher. Field survey indicated that the smaller version was not profitable and farmers preferred the bigger version to use in rental service. In 2009, the government provided a subsidy to farmers on the purchase of power thresher. Now, more than $90 \%$ of paddy and wheat are threshed by power thresher.

\section{Rice vision}

In 2015, BRRI prepared and published a policy paper on Rice Vision for Bangladesh: 2050 and beyond. BRRI identified several constraints and possible ways to overcome production barriers. This paper suggested that mechanized cultivation is one of the major interventions to achieve the goal. BRRI has taken initiatives to expand mechanized rice cultivation throughout the country (Kabir et al., 2015).

\section{Mechanization road map}

The government of Bangladesh formulated the "mechanization road map 2021, 2031, and 2041" in 2016. The road mapset the target of mechanical intervention in crop production (Table 1). The road map also encouraged the development partners to be involved actively in achieving the mechanization goal.

\section{Objectives of the study}

The labour shortage is becoming severe in crop production. Reduced availability of human labour due to shifting the off-farm wage workers to non-farm wage works and rising wages of off-farm workers mainly influenced farmers to introduce farm mechanization. The government of Bangladesh has also taken action plans to increase agricultural productivity. Farm mechanization is a vital determinant to increase agricultural productivity. This study aims to (i) estimate the mechanical intervention requirement for transplanting and harvesting operations of rice and (ii) delineate the impact of farm mechanization on rice productivity and employment generation.

Table 1. Short, medium and long-term target of bringing net rice cropped area (\%) under mechanical intervention of major intercultural activitiesin Bangladesh.

\begin{tabular}{lcccc}
\hline Activity & 2016 & Short- term (2021) & Medium-term (2031) & Long-term (2041) \\
\hline Seeding & 3 & 25 & 50 & 80 \\
Transplanting & 0.1 & 20 & 40 & 80 \\
Harvesting & 2 & 30 & 60 & 80 \\
\hline
\end{tabular}

Source: MoA, 2016 


\section{METHODOLOGY}

The primary data was collected through a household survey and key informant interviews (KII) which were used for projecting rice area, labour requirement, and off-farm employment opportunities for rice cultivation.

Besides, secondary data was collected from published literature. Table 2 presents the projected area under rice cultivation and rice labour scenario during 2016-2050. The labour scenarios were calculated based on per hectare 5 man-days labour required for raising seedling and transplanting rice by transplanter (operator-1, labour (skilled+unskilled)-2, seedling carrying labour-2) (Islam, 2017) and 4 man-days labour (operator-1, unskilled labour1 , bag carrying -2) require for harvesting by the combine harvester.

\section{RESULTS AND DISCUSSION}

\section{Farm power availability}

Farm power availability is one of the indicators of measuring the mechanization status of a country. The availability of farm power was estimated based on the energy input per unit area of cultivable land. Figure 1 shows the farm power availability in agriculture from 1960 to 2019. Before 1984, power availability in agricultural operations was very low. From 1960 to 1984, the rate of farm power increase was $1.2 \%$. The rate of farm power availability sharply increased to $10 \%$ after 2008 because of the large-scale adoption of farm machinery due to supportive government policy and activities of different stakeholders. The progression on the farm power availability in the farming sector has been continuingand it will be reached at 6.0 $\mathrm{kW} \mathrm{ha-1}$ in 2050 (Kabir et al., 2020) because of strengthening policy supports through providing subsidies on farm machinery purchase and reducing the tariff on farm machinery import (Islam, 2018b).

\section{Labour scenarios}

The lack of availability of labour at transplanting and harvesting period of rice affected productivity and increased production cost as wages gone up at the peak season, consequently rice cultivation becomes less profitable under manual transplanting and harvesting. It was also the case that farmers are forced to delay transplanting and harvesting rice because of the unavailability of off-farm wage workers. It not only decreases rice yield but also sometimes increases postharvest loss or completely damages Boro rice by heavy rain fall or hill surge. Figure 2 presents the labour demand calendar for rice cultivation both for traditional and mechanical operations. Labour requirements for manual harvesting were higher followed by transplanting operation. The wage rate also rises to a peak in the period of higher labour demand. However, mechanical intervention in transplanting and harvesting operations can minimize the seasonal labour crisis.

Table 2. Rice area, labour availability and labour requirement for rice cultivation under future conditions (2020-2050).

\begin{tabular}{cccccc}
\hline Year & $\begin{array}{c}\text { Rice area } \\
(\mathrm{M} \mathrm{ha})\end{array}$ & $\begin{array}{c}\text { Availability of rice } \\
\text { labour }(\mathrm{M})\end{array}$ & $\begin{array}{c}\text { Labour } \\
\left(\text { ha }^{-1}\right)\end{array}$ & $\begin{array}{c}\text { Labourrequirement } \\
(\mathrm{M})\end{array}$ & Deficit (M) \\
\hline 2016 & $5.59^{*}$ & $16.08^{*}$ & 2.88 & 16.08 & 0.00 \\
2020 & 5.50 & 15.06 & 2.74 & 15.83 & -0.77 \\
2025 & 5.39 & 13.97 & 2.59 & 15.51 & -1.54 \\
2030 & 5.28 & 12.56 & 2.38 & 15.21 & -2.65 \\
2035 & 5.18 & 11.50 & 2.22 & 14.90 & -3.40 \\
2040 & 5.08 & 10.34 & 2.04 & 14.61 & -4.27 \\
2045 & 4.98 & 9.17 & 1.84 & 14.32 & -5.15 \\
2050 & 4.88 & 8.00 & 1.64 & 14.03 & -6.03 \\
\hline
\end{tabular}

Source: Author's calculation based on Kabir et al., 2015 


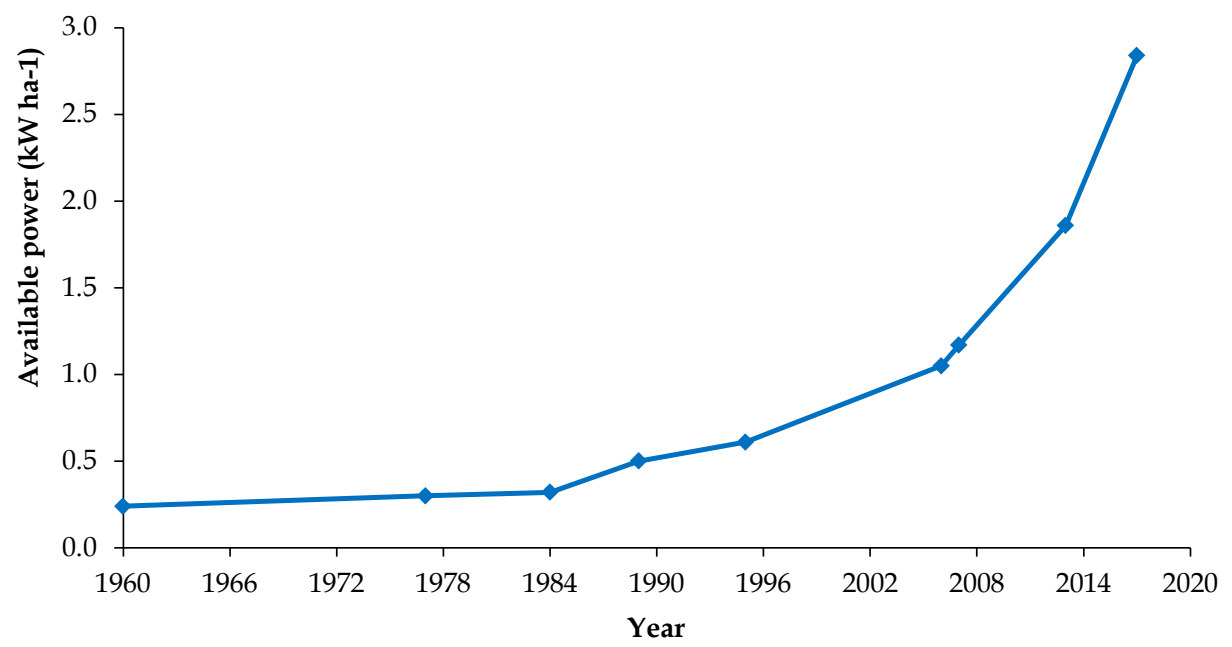

Fig. 1. Farm power availability in the agriculture sector in Bangladesh.

Source: Prepared by the author using the data from Islam, 2010; CSAM, 2015 and Islam, 2018a

Table 4 presents the availability of off-farm labour situation. In Bangladesh, some of the districts are severe and moderate labour shortages in particular at the transplanting and harvesting season of rice. It was because (i) the younger generation prefers non-farm work as a better livelihood option than farming, and (ii) more off-farm labour from the districts shifted to non-farm wage work. The labour shortage districts are dependent on migratory labour from the labour surplus districts for the intercultural operations of rice crops. The districts with less than $25 \%$ of agriculture labour households are highly deficient in offfarm wage workers for farming and depend on migrated labour from labour surplus districts for transplanting and harvesting of rice crops (Table 4).

The break-even labour requirement for rice cultivation was 2.88 man-days per hectare. Rice labour decreases due to shifting the labour in the non-farm activities. After 2020, the country might face a severe labour shortage in rice production (Fig. 3). Therefore, mechanization remains as the option to offset the labour shortage in rice cultivation.

Table 3. Human labour requirement for manual and mechanized intercultural activities of rice cultivation.

\begin{tabular}{|c|c|c|c|}
\hline \multirow[b]{2}{*}{ Technology } & \multicolumn{2}{|c|}{ Labour requirement } & \multirow[t]{2}{*}{ Source } \\
\hline & $\begin{array}{c}\text { Manual } \\
(\text { man-hr ha-1) }\end{array}$ & $\begin{array}{c}\text { Machine, } \\
\left(\text { man-hr ha-1) }^{-1}\right.\end{array}$ & \\
\hline Transplanter & $123-150$ & $9-11$ & Islam et al., (2016) \\
\hline Prilled urea applicator & 4 & 4 & Islam et al., (2015b) \\
\hline USG applicator & 4 & 4 & Islam et al., (2015b) \\
\hline Weeder & 86 & 22 & Islam et al., (2017a) \\
\hline Reaper & $80-84$ & $9-10$ & Alam et al., (2014) \\
\hline Combine harvester & 61 & 21 & Hasan et al., (2019) \\
\hline Open drum thresher & $50-52$ & $20-22$ & Islam (2006) \\
\hline Close drum thresher & $50-52$ & $14-18$ & Islam (2006) \\
\hline Winnower (man-hr $\mathrm{t}^{-1}$ ) & 21 & 5 & Ahiduzzaman et al., (2000) \\
\hline
\end{tabular}




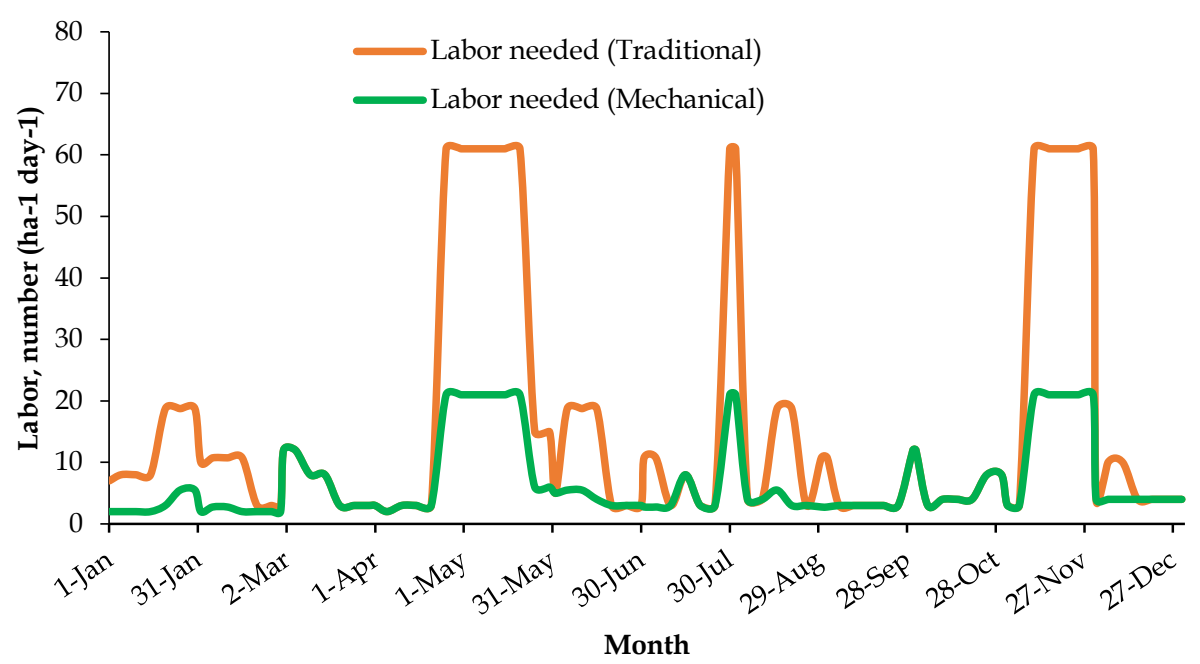

Fig. 2. Labour demand (manual and mechanical) calendar in rice production in Bangladesh. Source: Author calculation based on field survey 2020.

Table 4. Status of agriculture labour household in Bangladesh.

\begin{tabular}{|c|c|c|}
\hline $\begin{array}{l}\text { Farm } \\
\text { labour household }\end{array}$ & District & $\begin{array}{l}\text { Status(surplus } \\
\text { ordeficits) }\end{array}$ \\
\hline Less than $20 \%$ & $\begin{array}{l}\text { Dhaka, Narayanganj, Chittagong, Gazipur, Narshingdhi, } \\
\text { Jhalokhati, Sylhet }\end{array}$ & Highly deficit districts \\
\hline $21-25 \%$ & Feni, Munshiganj, Brahmanbari, Patuakhali & Deficit districts \\
\hline $26-30 \%$ & $\begin{array}{l}\text { Tangail, Manikganj, Rangamati, } \\
\text { Moulovibazar, Cox's Bazar, Barishal, } \\
\text { Barguna, Pirojpur, Khulna, Bandarban, } \\
\text { Comilla, Chapai Nawabganj }\end{array}$ & $\begin{array}{l}\text { Moderately deficit in } \\
\text { some area }\end{array}$ \\
\hline $31-35 \%$ & $\begin{array}{l}\text { Bhola, Bogra, Noakhali, Lakshipur, Pabna, Rajbari, Faridpur, } \\
\text { Gopalganj, Madaripur, } \\
\text { Magura, Kushtia, Narail, Sirajganj, } \\
\text { Panchagarh, Khagrachari, Chandpur }\end{array}$ & Sufficient \\
\hline $36-40 \%$ & $\begin{array}{l}\text { Rajshahi, Jenaidah, Chuadanga, Sunamganj, Joypurhat, } \\
\text { Sariatpur, Kishoreganj, Mymensingh, Habiganj, Rangpur, } \\
\text { Nilphamari }\end{array}$ & Surplus \\
\hline $41 \%$ and above & $\begin{array}{l}\text { Thakurgaon, Jashore, Netrakona, Jamalpur, Sherpur, Dinajpur, } \\
\text { Naogaon, Natore, Lalmonirhat, Gaibandha, Meherpur, } \\
\text { Kurigram, Satkhira }\end{array}$ & Highly Surplus \\
\hline
\end{tabular}

Source: BBS 2011 


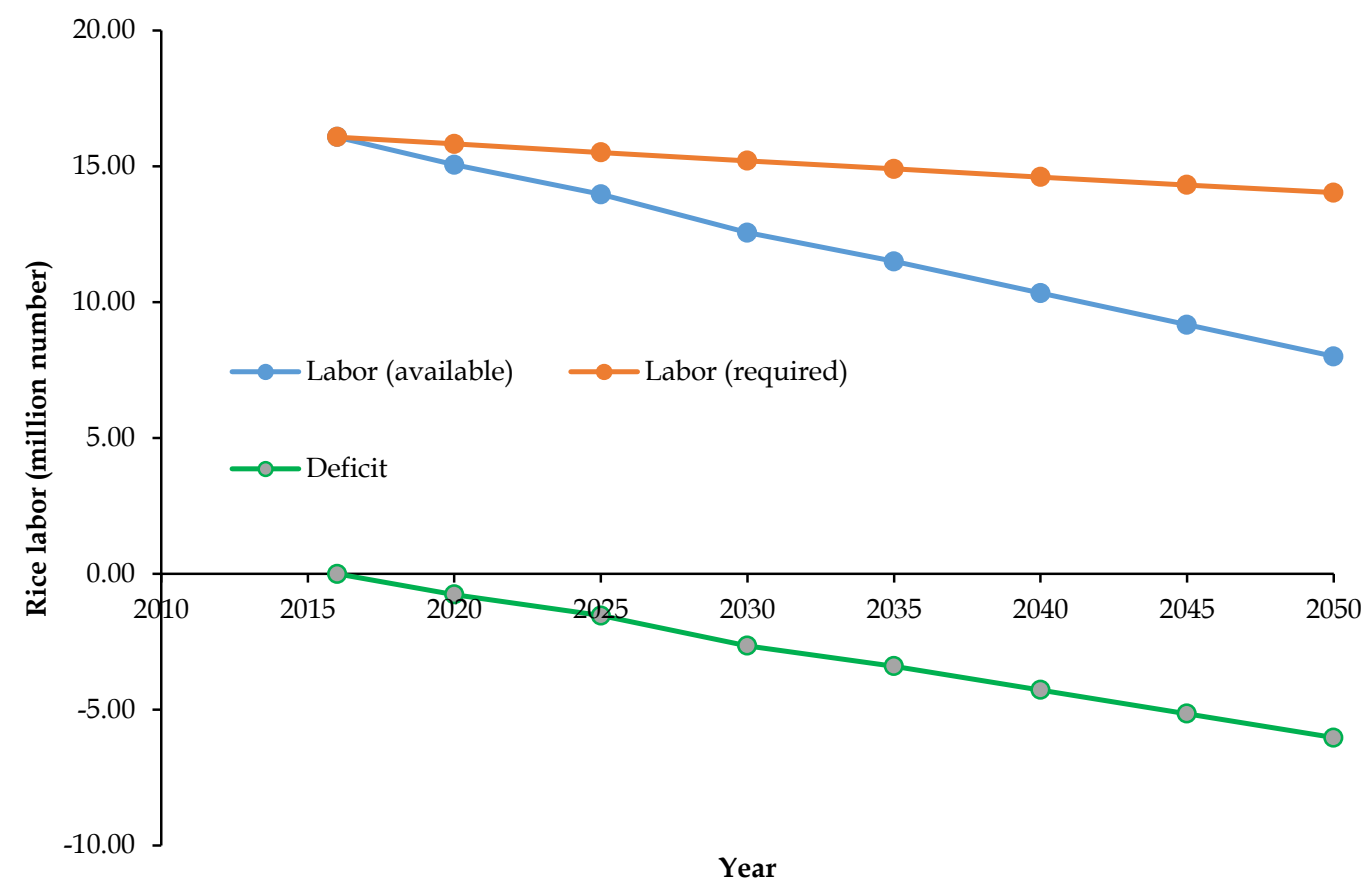

Fig. 3. Projected demand and supply of rice farming labour under future conditions (2016-2050) in Bangladesh. Note: Analysed and prepared by the author using data from Table 2

\section{Labour efficiency}

Table 5 presents comparative statements on the labour efficiency in manual and mechanical means of three major operations of rice cultivation are presented in Table 5. Transplanting by 4-row walking type transplanter, weeding by four-row power weeder and harvesting by mini combine harvester requires, respectively 29, 26, and
$34 \%$ of the total requirement for manual operation. Therefore, mechanized cultivation of rice is the only solution for increasingly decreasing labour availability for farming in rural Bangladesh. Labour efficiency could be doubled by 2030 if $42 \%$ and $36 \%$ of the total rice area goes under mechanical transplanting and harvesting, respectively (Tables 6 and 7).

Table 5. Labour efficiency under manual and mechanical operationsin Bangladesh.

\begin{tabular}{|c|c|c|c|c|}
\hline Activity & $\begin{array}{l}\text { Manual, } \\
\left(\text { md ha-1) }^{-1}\right.\end{array}$ & $\begin{array}{l}\text { Mechanical, } \\
\left(\mathrm{md} \mathrm{ha}^{-1}\right)\end{array}$ & $\begin{array}{l}\text { Labourrequirement } \\
\text { inmechanical operation (\%) }\end{array}$ & Source \\
\hline Transplanting & 19.00 & 5.50 & 29 & Islam et al., (2016) \\
\hline Weeding & 10.75 & 2.75 & 26 & $\begin{array}{l}\text { Islam et al., } \\
(2017 \mathrm{a})\end{array}$ \\
\hline Combine harvester & 61.00 & 21.00 & 34 & Hasan et al., 2019 \\
\hline
\end{tabular}

Note: $\mathrm{md} \mathrm{ha}^{-1}$ denotes man days per hectare 
Table 6. Projected yearly labour requirement (million) at different level of mechanical rice transplanting.

\begin{tabular}{cccccccccccc}
\hline & \multicolumn{1}{c}{ \%ear } & 35 & 40 & 45 & 50 & 55 & 60 & 65 & 70 & 75 & 80 \\
\cline { 2 - 9 } & 11.00 & 10.39 & 9.77 & 9.16 & 8.54 & 7.93 & 7.32 & 6.70 & 6.09 & 5.47 \\
2016 & 10.83 & 10.22 & 9.62 & 9.01 & 8.41 & 7.80 & 7.20 & 6.59 & 5.99 & 5.38 \\
2025 & 10.61 & 10.02 & 9.43 & 8.83 & 8.24 & 7.65 & 7.06 & 6.46 & 5.87 & 5.28 \\
2030 & 10.40 & 9.82 & 9.24 & 8.66 & 8.08 & 7.50 & 6.92 & 6.34 & 5.75 & 5.17 \\
2035 & 10.20 & 9.63 & 9.06 & 8.49 & 7.92 & 7.35 & 6.78 & 6.21 & 5.64 & 5.07 \\
2040 & 9.99 & 9.44 & 8.88 & 8.32 & 7.76 & 7.20 & 6.64 & 6.09 & 5.53 & 4.97 \\
2045 & 9.80 & 9.25 & 8.70 & 8.15 & 7.61 & 7.06 & 6.51 & 5.97 & 5.42 & 4.87 \\
2050 & 9.60 & 9.06 & 8.53 & 7.99 & 7.46 & 6.92 & 6.38 & 5.85 & 5.31 & 4.77 \\
\hline
\end{tabular}

Table 7. Projected yearly labour requirement (million) at different levels of mechanical rice harvesting.

\begin{tabular}{ccccccccccc}
\hline & \multicolumn{10}{c}{ \% mechanization } \\
\cline { 2 - 10 } Year & 35 & 40 & 45 & 50 & 55 & 60 & 65 & 70 & 75 & 80 \\
\hline 2016 & 10.32 & 9.61 & 8.89 & 8.18 & 7.47 & 6.76 & 6.04 & 5.33 & 4.62 & 3.91 \\
2020 & 10.15 & 9.45 & 8.75 & 8.05 & 7.35 & 6.65 & 5.95 & 5.25 & 4.55 & 3.84 \\
2025 & 9.95 & 9.27 & 8.58 & 7.89 & 7.20 & 6.52 & 5.83 & 5.14 & 4.46 & 3.77 \\
2030 & 9.76 & 9.08 & 8.41 & 7.73 & 7.06 & 6.39 & 5.71 & 5.04 & 4.37 & 3.69 \\
2035 & 9.56 & 8.90 & 8.24 & 7.58 & 6.92 & 6.26 & 5.60 & 4.94 & 4.28 & 3.62 \\
2040 & 9.37 & 8.73 & 8.08 & 7.43 & 6.78 & 6.14 & 5.49 & 4.84 & 4.20 & 3.55 \\
2045 & 9.19 & 8.55 & 7.92 & 7.28 & 6.65 & 6.02 & 5.38 & 4.75 & 4.11 & 3.48 \\
2050 & 9.00 & 8.38 & 7.76 & 7.14 & 6.52 & 5.90 & 5.27 & 4.65 & 4.03 & 3.41 \\
\hline
\end{tabular}

\section{Constrains in farm mechanizations}

Land size and shape. The present land ownership system in Bangladesh does not allow the movement of farm machinery from plots to plots. Besides, the land size of the country is mostly small, fragmented, and irregular in shape. The small and fragmented land restricts operating larger size farm machinery. Operational efficiency of the farm machines dependent on the plot size and shape. Therefore, the enlargement of land size is an urgent issue to promote farm mechanization in the country. Similarly it is reported that the small size of the plot decreases the field capacity of the farm machines (Islam, 2018b and Islam et al., 2017c). The field capacity of rice transplanters varied based on the size of the plots (Fig. 4).

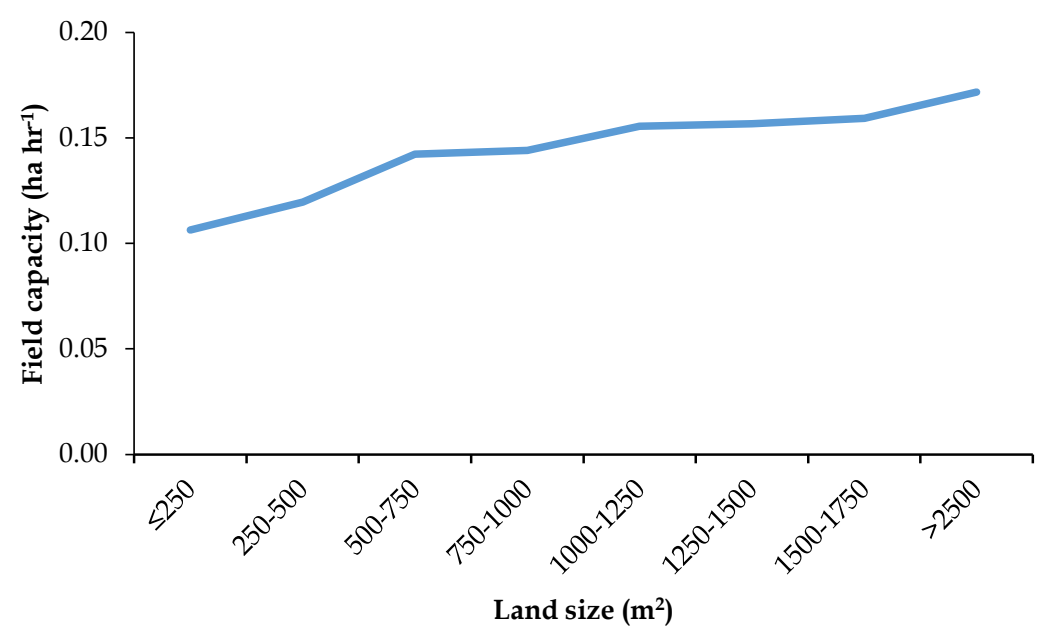

Fig. 4. Field capacity of transplanter with respect to land size.

Note: Graph adopted from Islam, 2018a.

56 Islam et al. 
The plot size equal to $1000 \mathrm{~m}^{2}$ or higher than that is the potential to achieve the optimum field capacity (e.g., $0.15 \mathrm{ha} \mathrm{hr}^{-1}$ ) of four-rows walking type transplanter. The field capacity of the transplanter was very low for the plot size below $250 \mathrm{~m}^{2}$. Islam et al. (2015a) reported that the plot size below $250 \mathrm{~m}^{2}$ and $400 \mathrm{~m}^{2}$ is not the potential to achieve the minimum level of field capacity of 4-row walking type transplanter and 6-row riding type transplanter, respectively.

The field capacity of the combine harvester continuosly increased with rises plot size due to decreased time waste for taking turns (Fig. 5). The field capacity of $750-1,000 \mathrm{~m}^{2}$ plot was $83 \%$ higher than the plot size below $500 \mathrm{~m}^{2}$. Field capacity of the combine harvester in the plot size below $500 \mathrm{~m}^{2}$ unable to achieve minimum economic threshold level. Therefore, the plot below $500 \mathrm{~m}^{2}$ is suitable for efficiently operating combine harvester.

Plot length-width ratio. Taniyama (1975) stated that the operation efficiency of farm machinery dependent on the size and the length (L) and width $(\mathrm{W})$ ratio of plots. The ratio of $\mathrm{L} / \mathrm{W}$ of plots has a notable influence on the performance of farm machinery. The total number of turning events depended on the $\mathrm{L} / \mathrm{W}$ ratio of the plots and operational path (length or widthwise). The least number of turns were observed for the L/W ratio of 2-2.5 and length-wise transplanting. The number of turning events of the farm machinery will be reduced in lengthwise operation and increased in width-wise layout. Length-wise operation of farm machinery is preferable to minimize the turning events. Plot length should be increased by keeping the same plot size (Islam et al., 2017c).

Land fragmentation. Fragmented land increased the plot to plot movement time. Land consolidation of the smaller plots may not be possible at this stage due to the socioeconomic condition of farmers. However, entrepreneurs may follow the operational consolidation by considering plot shape, size, and plot to plot distance while operating the farm machine in the field. Mandal (2017) and Islam et al. (2015a) recommended the operational consolidation for increasing the daily area coverage of the farm machine. Careful selection of the plots will reduce the lost time during turning, plot to plot movement, and consequently increase the daily area coverage (Islam et al., 2017c).

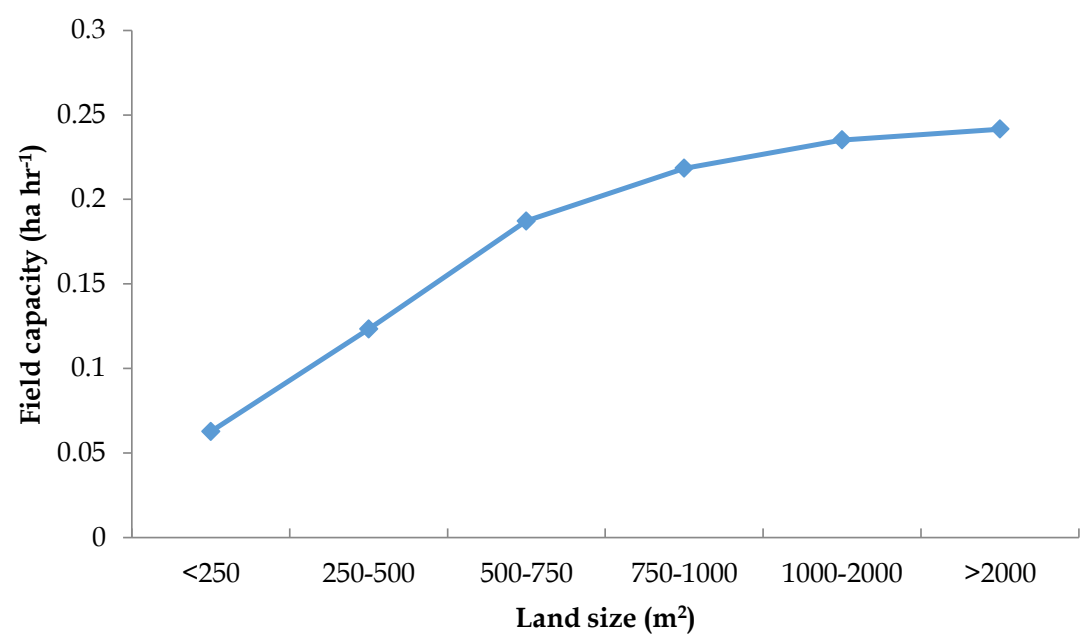

Fig. 5. Field capacity of combine harvester across plot size. Note: Graph adopted from Islam, 2018a. 
Time loss in turning. The total number of turns depends on the plot size and shape. Number of turning decreases with the increase of plot size (Fig. 6a). The size of plots is the determinant of the frequency of turning the requirement of plots. Therefore, the time loss for turning relied on the size of the plots. The time loss for turning decreases with an increase in the plot size (Fig. 6b). The turning time loss was high for the plot size below $500 \mathrm{~m}^{2}$. It is double for the plot size below $250 \mathrm{~m}^{2} \mathrm{compared}$ to plot about $500 \mathrm{~m}^{2}$. Turning time loss was also dependent on the skills of operators of the machine and the shape of the turning point. The economic threshold level of farm machinery could achieve through enhancing operators' skills and plots size over $500 \mathrm{~m}^{2}$.

Machinery movement in the field. The operators faced difficulty to move the machine on a sloppy surface as the height of the road from the field surface was observed as more than $2 \mathrm{~m}$. It caused damage to the machine and required extra care. Farm roads should be constructed to access the farm machinery in the land. According to Taniyama (1975), the layout of farm roads should be readjusted to facilitate the movement of farm machines to each field plot without causing damage to machines, levees, and irrigation channels. For Bangladesh, the height of main farm roads and branch farm roads should be $50 \mathrm{~cm}$ and $30 \mathrm{~cm}$ from the field surface, respectively. Sometimes, farm machinery movement damaged the irrigation channel and levees.

\section{Impact of mechanization on yield}

Table 8 presents the yield benefits of mechanized cultivation. It was observed that rice yield increases because of transplanting younger seedlings by transplanters than manual transplanting. Similarly, rice produced a higher rice yield for mechanized weeding and application of urea fertilizer. Likewise, mechanized harvesting by reapers and threshing by power threshers also reduces the grain loss compared to manual harvesting and threshing.

Impact of farm mechanization on employment

Traditionally it would believe that mechanization is not possible in the small and fragmented land and it will create unemployment problems in rural Bangladesh

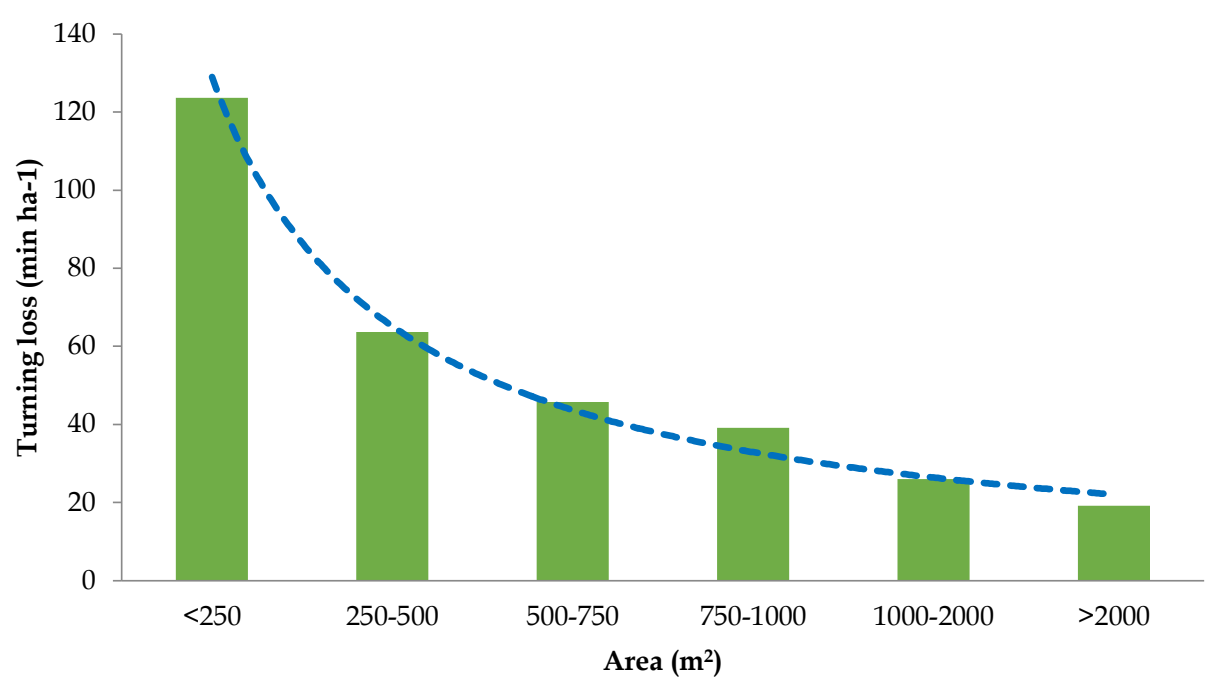

Fig. 6. Time loss for taking turns across plot size. 
(Ahmed, 1965; Alim, 1974). However, currently there are some districts in Bangladesh that are highly labour deficit despite fully mechanized tillage and threshing. It is also the case that mechanization creates employment opportunities for off-farm workers as operators. Besides, some people are working for servicing and fabricating the farm machinery. Moreover, some are involved in the business of spare parts and machinery. It indicates that mechanization plays a vital role in creating off and non-farm employment opportunities and improving the livelihood of rural dwellers. Table 9 presents the requirement of skills and unskilled manpower for mechanized transplanting and harvesting of rice in the country from 2016 to 2050.

\section{Entrepreneurial opportunity in farm machinery service business}

The development of entrepreneurship on rice transplanters and harvesters has broader scope for self-employment activities (Islam and Kabir, 2017). The private entrepreneurs, including farmers, provide services of farm machinery to the neighboring farmers. Transplanters and combine harvesters are highly investment intensive and require skilled operators to drive the machines. Besides, limited use of the types of machinery during the transplanting and harvesting season of rice is discouraged farmers from investing in those machines only for selffarming. Therefore, developing a business model for custom hire service of the machinery might facilitate to widespread adoption of mechanized transplanting and harvesting in the country. Custom hire services of farm machinery make an enabling environment to provide service to the farmers at the cheapest price (Islam et al., 2017b). The objective of the custom hire service is to foster farm mechanization by making easy access to the small and medium holder farmers. It also creates a business venture for the rural unemployed youths. Cash incentives should be provided to encourage entrepreneurs to set up the infrastructure of custom hiring services.

Table 8. Benefit of mechanized rice cultivationin Bangladesh.

\begin{tabular}{llll}
\hline Operation & Technology & Yield/output & Source \\
\hline Transplanting & Transplanter & $9-14 \%$ yield increase & Islam et al., (2016) \\
Weeding & Weeder & Increase & Islam et al., (2017a) \\
Urea fertilizer application & Prilled urea applicator & Increase & Islam et al., (2015b) \\
& USG applicator & Increase & Islam et al., (2015b) \\
Harvesting & Reaper & $0.26 \%$ loss over traditional & Alam et al., (2014) \\
Threshing & Mechanical thresher & $2-3 \%$ output increase & Islam (2006) \\
\hline
\end{tabular}

Table 9. Manpower requirements for mechanized rice cultivation in Bangladesh.

\begin{tabular}{cccc}
\hline Year & Mechanization (\%) & Operator+skilled labour (number) & Mechanic+Attendant (number) \\
\hline 2016 & $<1$ & 1216 & 61 \\
2020 & 15 & 81,647 & 4,082 \\
2025 & 28 & 148,358 & 7,418 \\
2030 & 38 & 196,687 & 9,834 \\
2035 & 56 & 282,190 & 14,109 \\
2040 & 76 & 375,373 & 18,769 \\
2045 & 84 & 403,898 & 20,195 \\
2050 & 90 & 419,819 & 20,991 \\
\hline
\end{tabular}

Source: Analysed and prepared by the author using data from field survey 2020 and KII 


\section{Power transplanters requirement}

The annual area coverage of four-row walking type and eight-row riding type transplanters was estimated considering per annum potentiality of the transplanters are 45 and 80 ha, respectively (Islam and Rahman, 2014). The demand for four/six-row transplanters was projected through accounting that $100 \%, 98 \%$, and $97 \%$ of total rice area would be transplanted by the fourrow walking type transplanters and the rest area would be transplanted by the eight-row rice transplanter, respectively by 2020, 2025 and 2030. The projected requirement of rice transplanters for $100 \%$ mechanical transplanting is $20,412,37,090$ and 49,172 for 2020, 2025, and 2030, respectively (Fig. 6).

\section{Combine harvester requirement}

The demand for combine harvesters was projected considering the annual harvesting capacity of a combine harvester is 70 ha (Islam, 2018a). The projected demand of the combine harvesters for mechanical harvesting of rice cropping area in Bangladesh is 11,662, 21,336, and 28,382 in 2020, 2025, and 2030, respectively (Fig. 7).

\section{Intervention required for mechanized farming}

Policy supports for disseminating power transplanters. Islam (2016) stated that the purchase price of the transplanter in Bangladesh is higher than that in Korea whereas labour price is the cheapest (12 times lower) in Bangladesh compared to Korea. On the other hand, the cost of manual transplanting is 7.5 times higher in Korea than in Bangladesh. In Bangladesh, farmers have to sell 18 tons of paddy to buy a transplanter whereas, in Korea, farmers can buy the same transplanter by selling 2.5 tons of paddy. Therefore, investment in mechanized transplanting is beyond the investment ability of most farmers, so that it requires government 60 Islam et al. support to make the transplanting venture viable (Islam, 2016). In 1981, the Korean government provided 50\% subsidy, 40\%loan, leaving farmers' own expense at ten percent (with an eight percent annual interest rate) to the organizations since 1986 to procure agricultural machinery to minimize the burden of the farmers. The loan repayment period of small farmers extended to seven years with a three-year grace period, and the interest rate decreased to $3 \%$. The repayment period of the credit, with which a farm household borrowed to purchase farm machines, was also extended to seven years with a five-year grace period (AMK, 2000). Bangladesh can follow the Korean mechanization policy considering the socio-economic conditions of the farmers. Islam (2016) also mentioned that cash incentives dependent on the annual area coverage by a transplanter. For a profitable custom hire service of transplanting,about $80 \%$ of the total price of a power transplanter needs to provide as a subsidyfor procuring a transplanter if a transplanter can transplant rice in the 15 ha area. However, the requirement of the subsidy decreased to $60 \%$ with an arrangement of $30 \%$ soft loan of the total price of the transplanters if the capacity increased to 25 ha.

\section{Policy supports for disseminating} combine harvesters. The government of Bangladesh has taken an action plan to promote mechanized harvesting in the country. The government provided $70 \%$ assistance for the haor areas and 50\% assistance for the other areas on the procurement of harvester in 2020. Field survey indicated that bigger size of the combine harvester is more business viable than small size. However, the price of bigger sizes combine harvester is beyond the purchasing power of the entrepreneurs. Due to the limited annual use and price of the machine, the incentive should be increased to $70 \%$ for all the areas, $20 \%$ soft loan, and the remainder of the ten percent farmer's expenses to create the 


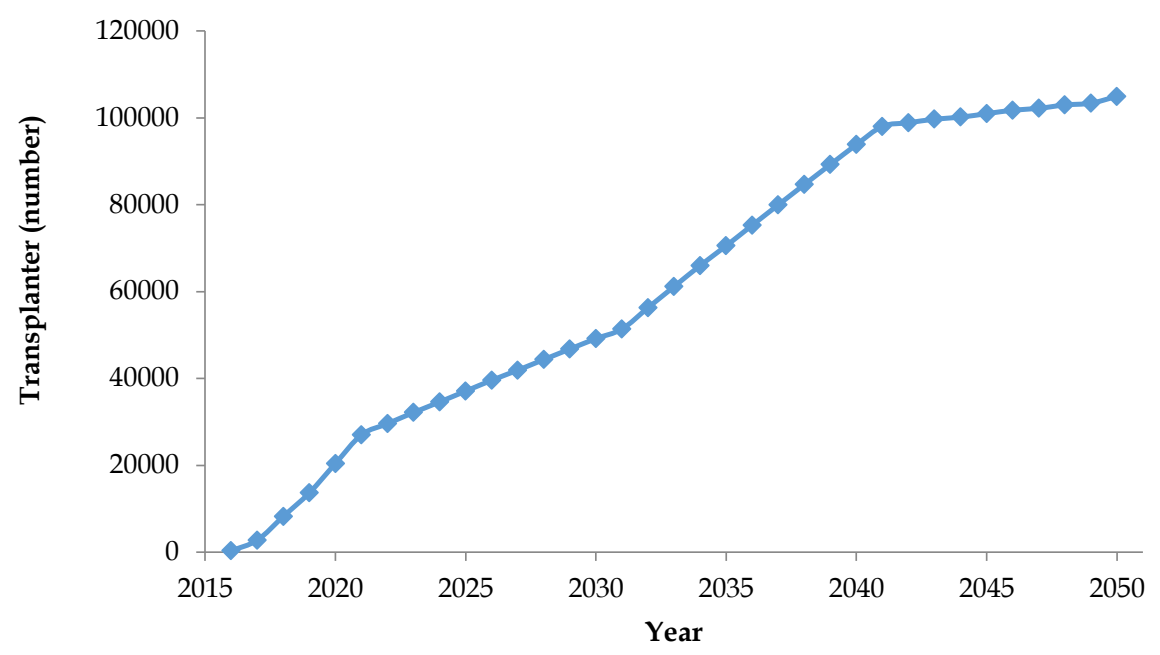

Fig. 6. Demand of rice transplanters for fully mechanized transplanting under future condition (2016-2050) in Bangladesh. Source: Analysed and prepared by the author using data from field survey 2020

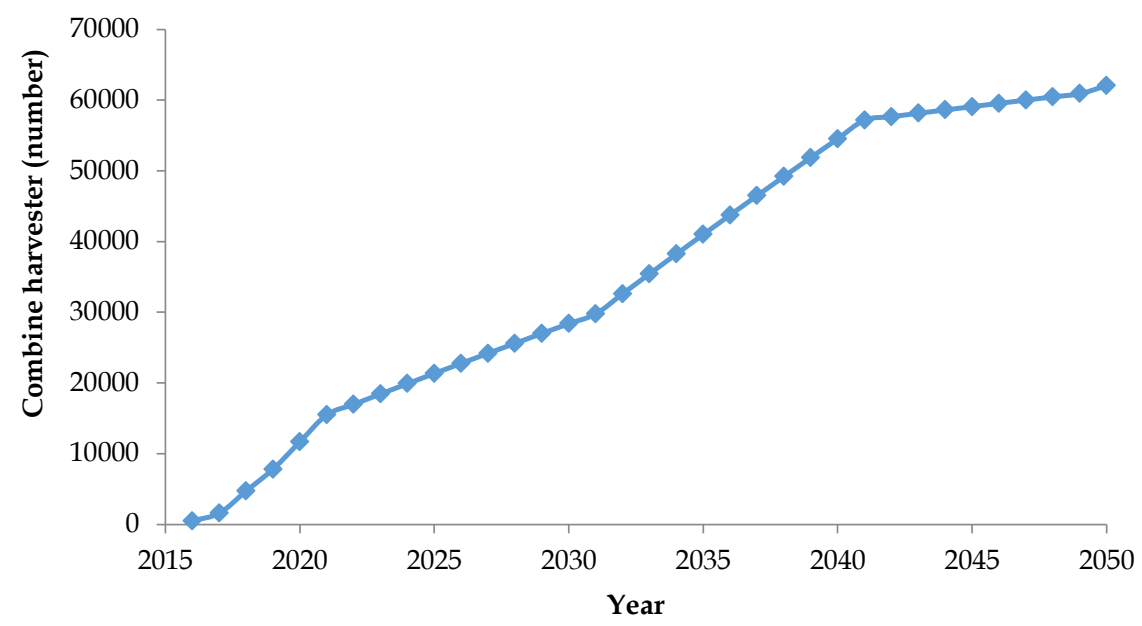

Fig. 7. Demand of combine harvester for mechanized rice harvesting under future conditions (2016-2050) in Bangladesh. Source: Analysed and prepared by the author using data from field survey 2020.

harvesting business more viable. The mentioned rate to service providers or entrepreneurs will contract with the farmers entrepreneurs to provide the services to the willing to harvest their rice crop by combine farmers at an affordable rental charge. Farmers harvester and prepare harvesting schedule have to use the quality seed for raising rice based on the position of the plots to provide seedlingsin the trays at their premises. The the service to them.

Business model for disseminating transplanter. A subsidy for procuring transplanters should provide as above seedling management on the trays is as like as they would traditionally practice for raising seedlings in the nursery. Local service providers or entrepreneurs will provide custom hire 
services of mechanical transplanting of rice using farmers' raising seedlings at trays.

Business strategies. Farm machinery entrepreneurs can move to another area after completing work in one area in a short time. This will enable them to run service business of farm machinery profitably and will play a helpful role in creating a business-friendly environment.

\section{Synchronize cultivation}

Synchronized cultivation is meant to transplant the variety having the same growth duration at the same time in certain areas to facilitate the transplanting and harvesting crops by machine. This will make the transplanting and harvesting business profitable and reduce the production cost of the farmer. Synchronize cultivation should be done within the command area of a deep tube well to ensure irrigation water supply as well.Larger size of the land is preferable to operate the farm machinery at full capacity. However, daily area coverage of farm machinery can be increased in small size of plot through cultivating variety having similar growth duration in the adjacent plots. Different varieties of the same crop with the same growth duration can also be cultivated. Then threshing drum should be cleaned thoroughly to avoid seed mixing while harvesting with a combine harvester. It is better to cultivate the same variety in the same area to avoid seed mixing. Besides, raising seedling in the trays enhance capacity of the transplanters. Seed germination should be above $95 \%$ to avoid missing hill. Seeds need to be purified before incubation. Not all seedlings can be raised on the same day in the trays. Seedlings need to be prepared in different steps within a week. Sprouted seeds should be sprinkled evenly in the trays, so that there is no gap in the fields. Uneven distribution of seed created patchy seedlings and ultimately increase the missing in the field. After sowing the seeds evenly, one layer of soil should be lightly applied. The top layer of soil should not be too thick. Manual transplanting should also follow the rows for easier inter-cultural operations and operating combine harvesters. The fields located in the far should transplant earlier to reduce the time loss. However, the harvesting should commence from the adjacent plots. In order to expedite and popularize farm mechanization at the field level, under the supervision of the Ministry of Agriculture, Department of Agriculture Extension in association with BRRI experimentally started to synchronize cultivation in 20 acres of land in some selected blocks in each of the 12 districts of the country in the Boro 2019-20 (Field survey, 2020).

BRRI may provide facilitate synchronized farming through supporting to select rice variety and farm machinery, recommend fertilizer dose, giving advisory services on diseases and insect control methods, increasing cropping intensity i.e., productivity, monitoring farming activities around the crop period and the creation of entrepreneurs.

The synchronized cultivation is the potential to reduce time loss for moving farm machinery from one plot to another. Besides, the operating area of farm machinery will increase ormore land will be transplanted and harvested in a day because of synchronized cultivation. Moreover, water management and weeding will be carried out efficiently under synchronize cultivation. Furthermore, disease and insect pests infestation will be less and pest controlwill be easier. Therefore, mechanized cultivation will be profitable even in the small plots under synchronized cultivation (Fig. 8). 


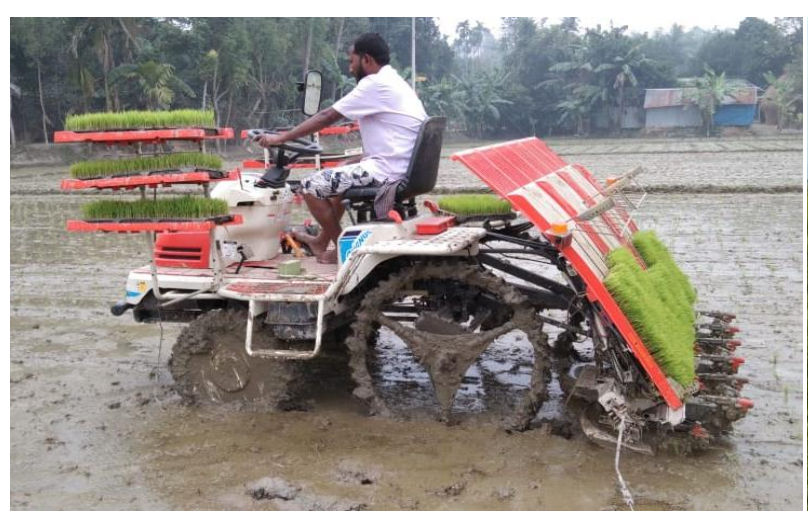

Transplanting

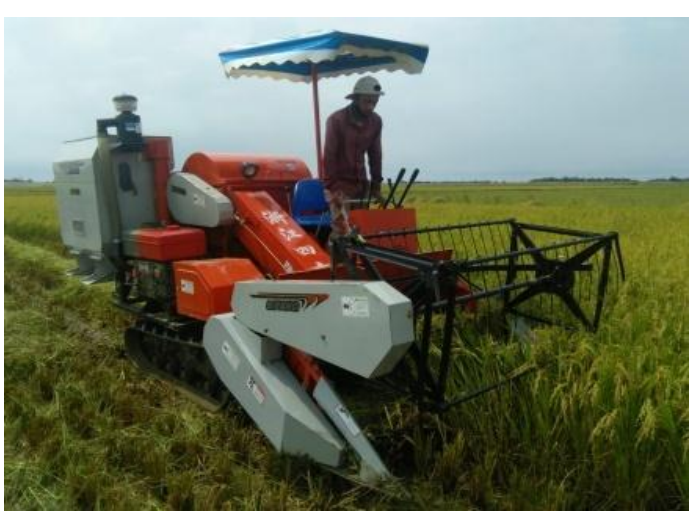

Harvesting

Fig. 8. Transplanting and harvesting in synchronize plot.

Development of skilled operators. Trained and skilled drivers are essential for efficiently operating the farm machinery. The operators must know the strategy of transplanting seedlings in the headland. The operators should know the approach of driving the machine efficiently in the plots surrounded by crops on its two or three sides. Transplanting and harvesting machine should operate at walking speed. Sudden turns should be avoided to prevent accident.

\section{Implementation strategy}

The goal of fully mechanize farming may not be feasible to achieve by only government intervention. It requires combined interventions including the public (e.g., ministry, research and extension), private stakeholders (traders, manufacturers and mass media), and development partners. The policy supports are needed for achieving the following strategies:

- Cash subsidies to service providers or entrepreneurs, including farmers to purchase transplanters, reapers, and combine harvesters should continue and strengthen.

- BRRI may provide hands-on training to the agricultural engineers, sub-assistant agricultural officers, farmers, and operators on tray preparation techniques, operation, re- pair, maintenance, and supervision of farm machinery.

- The capacity of DAE should strengthen through establishing an agricultural engineering wing for rapid dissemination of the farm machinery and associated technology as well as to provide training for developing skilled manpower for operating and maintenance of the farm machines.

- The government cash supports should strengthen for developing entrepreneurship for hiring out farm machinery at custom hire basis, marketing farm machinery, and workshop for fabricating machines.

- The business model for the different types of farm machinery should develop to run the service business profitably.

- Extension service should be strengthening for mechanical transplanting in a location using the rice variety having similar growth duration (i.e., called synchronize farming) to facilitate mechanical harvesting the rice at a time for creating a business opportunity for rental service providers.

\section{Action plan}

An action plan has been prepared with ten years interval to achieve the target of mechanized cultivation in 2030 and beyond (Table 10). 
Table 10. Action plan of mechanized cultivation.

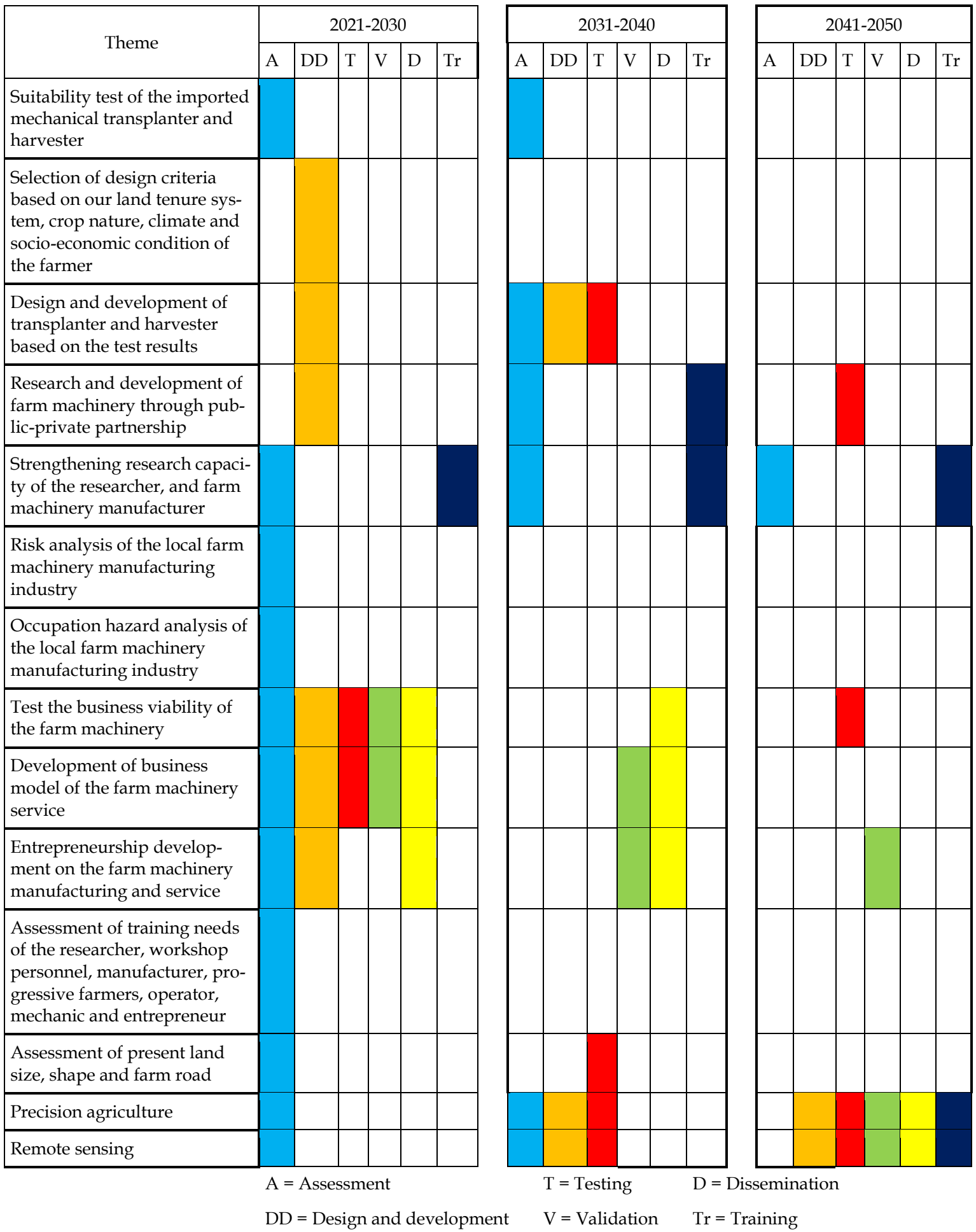

64 Islam et al. 


\section{CONCLUSION}

Labour efficiency might double by 2030 subject to bring $42 \%$ and $36 \%$ of total rice area under mechanical transplanting and harvesting, respectively. The large-scale dissemination of mechanical transplanting and harvesting will be facilitated to transplant rice within the optimum planting period and harvest the rice crops without delay. As a result, the unexpected yield loss of stape food crops due to delay transplanting and harvesting due to the unavailability of labour will be reduced substantially. Synchronize rice farming is essential to optimize the field efficiency of the farm machine under the present size and shape of the plots. Besides, synchronize farming is beneficial for providing service to the farmers at their affordable rental charge. Government supports for the procurement of transplanters and combine harvesters should continue and further strengthen.

\section{RECOMMENDATION}

- Sufficient funds should be allocated to promote the mechanized farming.

- Strengthening local farm machinery manufacturing industries.

- Hands-on training should be arranged to develop skilled operator and mechanic.

\section{ACKNOWLEDGEMENT}

The author acknowledges the contribution of Dr Md Shahjahan Kabir, Dr Moin Us Salam, Md Abdur Rouf Sarkar, Md Abdullah Al Mamun, Dr Md Jahangir Kabir and scientistsof Farm Machinery and Postharvest Technology Division, Bangladesh Rice Research Institute.

\section{DECLARATION OF INTERESTS}

A version of the paper was published in a book "Doubling Rice Productivity in Bangladesh" in 2020 by the Bangladesh Rice Research Institute (BRRI), Gazipur 1701, Bangladesh to commemorate BRRI's $50^{\text {th }}$ anniversary. The Bangladesh Rice Journal has prior knowledge of the book publication and does not see any conflict of interest.

\section{REFERENCES}

Ahmed, K. 1965. Agriculture in East Pakistan. Polwel Printing Press. Dhaka: Bangladesh.

Ahiduzzaman, M, M Baqui and A K M S Islam. 2000. Test of BRRI Winnower. Experiment report, Bangladesh Rice Research Institute, Farm Machinery and Postharvest Technology Division, Gazipur.

Alam, M A, M A Hossen, A K M S Islam, S Paul and M A Rahman. 2014. Performance evaluation of different types of reaper. Proceedings of BRRI annual research review workshop 2013-14. Bangladesh Rice Research Institute, Gazipur-1701.

Alim, A. 1974. An introduction to Bangladesh agriculture. Swadesh Printing Press, Dhaka: Bangladesh.

A M K, 2000. Agricultural mechanization in Korea. The Korean Society for Agricultural Machinery. ISBN:8985929-00-3 93550.

Anonymous, 2014. Agriculture labourers of Bangladesh: Entrapped in unviable production relations. Submitted to FNV Mondiaal Netherlands Trade Union Confederation.

BBS (Bangladesh Bureau of Statistics). 2011. Yearbook of Agricultural Statistics of Bangladesh 2011, July 2011, Government of Bangladesh.

CSAM (Centre for Sustainable Agricultural Mechanization). 2015. Agricultural mechanization and testing of agricultural machinery in the AsiaPacific region.The Centre for Sustainable Agricultural Mechanization, United Nations Economic and Social Commission for Asia and the Pacific (UNESCAP). p160.

Hasan, M K, M R Ali, C K Saha, M M Alam and M M Hossain. 2019. Assessment of paddy harvesting practices of Southern Delta Region in Bangladesh. Progressive Agriculture, 30 (1): 57-64.

Islam, A K M S. 2018a. Rice mechanization in Bangladesh. Publication number 260. Bangladesh Rice Research Institute, Gazipur, Bangladesh.

Islam, A K M S. 2018b. Status of rice farming mechanization in Bangladesh. Journal of Bioscience and Agriculture Research, 17 (01):1386-1395.

Islam, A K M S and M J Kabir. 2017. Rental service market of farm machinery in rice cultivation: an investigation at farm level. Bangladesh Rice Journal. 21 (1): 35-45. 
Islam, A K M S, M T Islam, M S H Islam, A K M L Rahman and M A Rahman. 2017a. Performance evaluation of BRRI power weeder for low land rice (Oryza sativa L.) cultivation. The Agriculturists, 15 (1): 40-48.

Islam, A K M S, M S Rahman, S R Das, T K Saha, M R Rahman, M T Islam and Rabbani. 2017b. Entrepreneurial opportunity of mechanical rice transplanting service for smallholder farmer in Bangladesh. Progressive Agriculture, 28 (3): 230-239.

Islam, A K M S, M S Kabir and M I Hossain. 2017c. Present land size with shape and effect on the operational efficiency of rice transplanter. Journal of Science Technolology Environmentand Information, 05 (02): 402-412.

Islam, A K M S. 2016. Mechanized rice transplanting in Bangladesh. Publication number 218. Bangladesh Rice Research Institute, Gazipur, Bangladesh.

Islam, A K M S, M A Rahman, A K M L Rahman, M T Islam and M I Rahman. 2016. Techno-economic performance of 4-row self-propelled mechanical rice transplanter at farmers' field in Bangladesh. Progressive Agriculture, 27 (3): 369-382.

Islam, A K M S, M T Islam, M A Rabbani, M A Rahman and A B M Z Rahman. 2015a. Commercial mechanical rice transplanting under public-private partnership in Bangladesh. Journal of Bioscience and Agriculture Research, 06 (01): 501-511.

Islam, A K M S, M A Rahman, A K M L Rahman, M T Islam andMI Rahman. 2015b. Field Performance evaluation of push-type BRRI prilled urea applicator in low land rice cultivation. Bangladesh Rice Journal. 19 (2) : 68-78.

Islam, A K M S and M A Rahman. 2014. Evaluation of Tegra over traditional method of rice transplanting. Report submitted to Syngenta Bangladesh Limited, Dhaka, Bangladesh.

Islam, A K M S. 2006. Performance evaluation of thresher. Report submitted to the FMPHT Division, Bangladesh Rice Research Institute, Gazipur, Bangladesh.
Islam, M S. 2010. Farm mechanization for sustainable agriculture in Bangladesh: problems and prospects. FMPE Division, BARI, Gazipur, Bangladesh.

Kabir, M S, M U Salam, A Chowdhury, N M F Rahman, K M Iftekharuddaula, M S Rahman, H Rashid, S S Dipti, A Islam, M A Latif, A K M S Islam, M M Hossain and J K Biswas. 2015. Rice vision for Bangladesh: 2050 and beyond.Bangladesh Rice Journal, 19 (2) :1-18.

Kabir, M S, M U Salam, A K M S Islam, M A R Sarkar, M A A Mamun, M C Rahman, B Nessa, M J Kabir, H B Shozib, M B Hossain, A Chowdhury, M Nasim, K M Iftekharuddaula, M S Hossain, M K A Bhuiyan, B Karmakar, M S Rahman, M M Haque, M T Khatun, M P Ali, S M H A Rabbi, P L Biswas, E S M H Rashid and N M F Rahman. 2020. Doubling rice productivity in Bangladesh: A way to achieving SDG2 and moving forward. Bangladesh Rice Journal, 24 (2): 1-47.

Mandal, M A S. 2014. Agricultural mechanization in Bangladesh: role of policies and emerging private sector. In: Paper presented at the NSD-IFPRI Workshop on "Mechanization and Agricultural Transformation in Asia and Africa: Sharing Development Experiences". June 18-19, 2014 Beijing, China. Available from URL: http://www. slideshare.net/IFPRIDSG/sattar-mandal?related=2 (accessed on 07.07.16).

MoA (Ministry of Agriculture). 2016. Agricultural mechanization road map 2021, 2031, 2041.Ministry of Agriculture, Secretariat of Bangladesh.

MoA (Ministry of Agriculture). 2020.https:/ / moa.gov.bd/ site/news/730e50c2-0429-4bf4-9b47-c06b9a 500027 (Accessed on 20/04/2020).

Taniyama, S. 1975. Land consolidation in paddy fields. In: Symposium on water management in rice fields ed. by Tropical Agricultural Research Center, Ministry of Agriculture and Forestry, Tokyo. 